\title{
The Difficult Way to Publish a Research Paper
}

\author{
Kuat Oshakbayev $^{1 *}(\mathbb{D})$, Gulnara Bedelbayeva ${ }^{2}$ (D) Khalit Mustafin $^{3}$ (D) Attila Tordai $^{4}$ (D) \\ ${ }^{1}$ Department of Metabolic Syndrome, National Research Oncology Center, Astana, Kazakhstan; ${ }^{2}$ Department of Ambulance \\ Urgent Medical Help, Kazakh National Medical University Named Asfendiarov, Almaty, Kazakhstan; ${ }^{3}$ Department of Surgery, \\ National Center of Neurosurgery, National Research Oncology Center, Astana, Kazakhstan; ${ }^{4}$ Department of Pathophysiology, \\ Semmelweis University, Budapest, Hungary
}

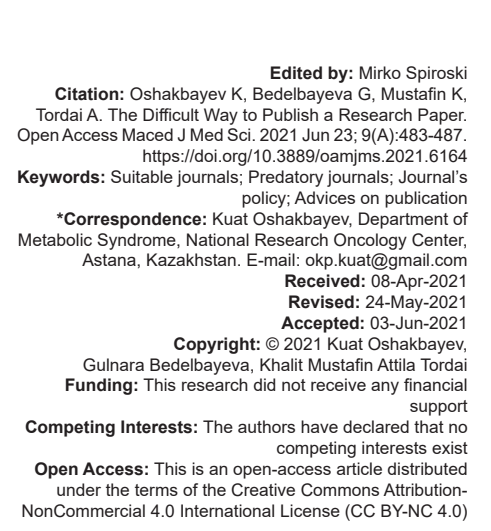

\section{Abstract}

BACKGROUND: The authors aim to publish the results of their studies in peer-reviewed targeted international journals with a high impact-factor as possible, but they are also exposing to "predatory" publishers.

AIM: The aim of the study was to offer some advices for authors to help to identify relevant medical journals, avoid "predatory" journals and publishers, use intermediary services, know a journal policy, and expectations of good journal editor(s).

RECOMMENDATIONS: During the publication process authors should find suitable journals, assume a risk to encounter "predatory" or "hijacked" journals, know the advantages and disadvantages of using intermediary publishing services, understand expectations of editor(s), and make payment for article processing.

CONCLUSIONS: The advices can help many researchers to publish their papers in relevant journals with cited indexes, and avoid many problems within the publication process.

\section{Introduction}

Many authors are attracted to publish their research results in peer-reviewed high impacted, as possible, international journals. This activity is a requirement for career development and progression, also for obtaining a grant support [1].

The number of scientific medical journals has increased exponentially in the last two decades, and hundreds of thousands of articles appear annually. At the same time, many authors have been affecting by "predatory" publishers offering rapid publication of their articles.

As a general rule, authors do not choose "predatory" journals intentionally [2], [3], they are attracted to these journals by the "predatory publishers" with deceptive advertising. However, the consequences may be very serious as many leading universities can either dismiss the authors of such manuscripts or ask for refunding of research grants obtained.

Predatory journals growth as infectious contagious phenomenon: if in 2010 twenty journals published 53,000 articles, whereas in 2016 over 1,000 journals published more than 500,000 articles, earning around 74 million USD [4]. Potential predatory openaccess publishers are widely present in the broad field of medicine. Researchers should carefully check journals' information before submitting their papers.

Facing new times, we have new challenge: to be discerning about journals where to publish our work. In fact, doctors and nurses have taken a leadership role in identifying the problem of predatory publishing and coming up with potential solutions to address [5], [6]. The aim of the study was to offer some advices for researchers to help to identify relevant medical journals, avoid "predatory" journals and publishers, use intermediary services, know a journal policy, and expectations of good journal editor(s).

\section{Practical Recommendations}

Publishing research results in peer-reviewed journals need to have a novelty or unique case that can impress editors and their scientific community. Journal's editor is as mediator who tries to attract own readers to own journal using author(-s)' study results. The study results must be repeatable and 
confirmed by evidence based methods and data. Some practical recommendations for researchers during their publishing process are presented in Table 1.

Table 1: Practical recommendations for researchers during publishing process

\begin{tabular}{|c|c|c|}
\hline \# & Emerging challenges & Advice to take into consideration \\
\hline 1 & $\begin{array}{l}\text { Predatory publishers } \\
\text { and journals }\end{array}$ & $\begin{array}{l}\text { 1. have only a commercial interest } \\
\text { 2. always open access } \\
\text { 3. no peer review } \\
\text { 4. breeding ground for types of unethical behaviors }\end{array}$ \\
\hline 2 & $\begin{array}{l}\text { Hijacked journals } \\
\text { and international } \\
\text { conferences }\end{array}$ & $\begin{array}{l}\text { 1. "imitates" legally functioning original journals and/or } \\
\text { prominent international conferences } \\
\text { 2. hijackes websites' names, addresses, citation index, } \\
\text { international publication numbers, publication fees, etc. }\end{array}$ \\
\hline 3 & $\begin{array}{l}\text { To find a suitable } \\
\text { journal use the } \\
\text { services }\end{array}$ & $\begin{array}{l}\text { 1. "Find journals" label of Elsevier (Scopus) journals' website } \\
\text { 2. "Match" label on the website "EndNote" of Web of } \\
\text { Science's Journal Citation Reports (Clarivate Analytics) } \\
\text { 3. "Journal suggester" label in Springer-Nature journals } \\
\text { 4. "Journal suggester" label in Taylor and Francis journals } \\
\text { 5. "Journal Finder Beta" label in Wiley journals }\end{array}$ \\
\hline 4 & $\begin{array}{l}\text { To make sure that the } \\
\text { chosen journal is not } \\
\text { predatory: }\end{array}$ & $\begin{array}{l}\text { 1. check the "real" existence of the journal on Web Of } \\
\text { Science (Clarivate Analytics) or Scopus (Elsevier) } \\
\text { scientometric bases } \\
\text { 2. point out on a quality of a peer review } \\
\text { 3. visit the journal website, explore his aim and scope, } \\
\text { editorial board, previous published articles } \\
\text { 4. visit the journal website through hyperlinks of the } \\
\text { scientometric bases }\end{array}$ \\
\hline 5 & $\begin{array}{l}\text { To think about use of } \\
\text { intermediary services } \\
\text { to publish a paper: }\end{array}$ & $\begin{array}{l}\text { 1. As a rule, the services choose journals with a low impact } \\
\text { factor } \\
\text { 2. The services include additional costs } \\
\text { 3. The services often are fraudsters }\end{array}$ \\
\hline 6 & $\begin{array}{l}\text { An ethical issue } \\
\text { on Journals' Policy } \\
\text { prohibiting authors to } \\
\text { submit their manuscript } \\
\text { to more than one } \\
\text { journal simultaneously: }\end{array}$ & $\begin{array}{l}\text { 1. It is important to avoid paper duplication } \\
\text { 2. A chance to improve own paper under comments from } \\
\text { previous review(s) } \\
\text { 3. Nevertheless, the policy } \\
\text { 4. Extends the time of authors being published } \\
\text { 5. Increases risks to lose of authors' copyright, scientific and } \\
\text { practical priority } \\
\text { 6. Does not choose a better journal after submitting } \\
\text { 7. Restricts the rights of authors to be published first }\end{array}$ \\
\hline 7 & $\begin{array}{l}\text { Fees charged for } \\
\text { publication and } \\
\text { payment: }\end{array}$ & $\begin{array}{l}\text { 1. many journals do not request article-processing charges } \\
\text { 2. most clinical journals request article-processing charges } \\
\text { 3. most open access journals request article-processing } \\
\text { charges } \\
\text { 4. a number of open access journals is increasing time by time }\end{array}$ \\
\hline 8 & $\begin{array}{l}\text { Authors who are going } \\
\text { to pay publication fees } \\
\text { by themselves: }\end{array}$ & $\begin{array}{l}\text { 1. pay by credit card using a secure payment link through } \\
\text { an electronic portal provided by the journal, or by bank } \\
\text { transfer issuing an invoice number through an account } \\
\text { provided by the journal } \\
\text { 2. the publication payment includes bank fee and VAT } \\
\text { charges } \\
\text { 3. keep on your credit card not exceeding twofold of the } \\
\text { publication fee to avoid two times remittance due to } \\
\text { various computer and bank errors } \\
\text { 4. pay note on a specific deadline for payment transaction }\end{array}$ \\
\hline
\end{tabular}

Predatory publishers and journals are growing as microbial contamination, and it has a serious threat for scientific community. "Predatory" journals have only a commercial interest and aim to get an income as easily and rapidly as possible. Predatory journals can be confused with reputable open access journals. Jeffrey Beall (University of Colorado in Denver, USA) was first used the term "predatory publishers" established 48 criteria for "predatory" journals [7]. From 2008, he regularly published the list of possible or potential "predatory" journals on his website (www.scholarlyoa.com), reaching the number of 1000 publishers and journals by the end of 2016 . Meanwhile, other researchers proposed additional criteria for "predatory" journals [8]. In January, 2017, Beall closed the website, and Beall's list stopped operating "for unknown reasons." By exploiting gold open access publishing, predatory journals paved the way for low-quality articles that threatened to change the landscape of evidence-based science [9]. Predatory journals always are open access, but the problem is not open access. The problem is predatory journals failing of proper peer review practices, also the journals are not reading by anybody and citing by nobody, but in an extremely exceptional case [10]. Peer review remains an essential matter, the cornerstone of scientific publishing. Predatory journals also create a breeding ground for types of unethical behaviors, such as plagiarism, falsification, and fabrication.

From 2012, "hijacked journals", a new type of fraud, have appeared; these are journals "imitating" other journals. In 2012-2013 only, over 20 "hijacked journals" emerged and by 2019 over 1500 journals were on this list [11]. Hijacking of scientific journals consists of websites created in place of the ones of true academic journals by copying their names, addresses, citation index, and international publication numbers to steal their publication fees also. Hijacked journals imitate legally functioning journals, often through the change in one character of the original website name. Hijacked journals copy original journals from any country and continent. It is extremely difficult to identify and block hijacked journals as their domain servers are generally outside these countries [12].

Recently similar frauds have affected international conferences. The fraudsters copy data of official international associations which hold annual scientific conferences, and invite through e-mail potential authors to submit presentations to a fake conference. These fake conferences are generally planned to be held in the United Kingdom, USA or Germany, and other countries of the Organization for Economic Cooperation and Development [13]. Obviously those conferences will never take place, and after receiving registration fees the conference's website disappears. At best a conference will not satisfy the expectations of authors and will be a waste of money.

\section{How to Find a Suitable Journal for Your Article}

Publishing in Elsevier (Scopus) journals use the service "Find journals" on their website; to publish in journals with an active impact factor listed in Web of Science's Journal Citation Reports (JCR, Clarivate Analytics) use the "match" label on the website "EndNote"; publishing in Springer-Nature or Taylor and Francis journals use "Journal suggester" services; to publish in Wiley journals use "Journal Finder Beta". 


\section{How to Make Sure that the Chosen Journal is Not Predatory}

(1) Check the "real" existence of the journal and confirm its citation index on Web Of Science (Clarivate Analytics) or Scopus (Elsevier) websites; (2) point out on an existence and quality of a review; and (3) visit the journal website, explore his aim and scope, look at relevant skills of the editorial board, and previous published articles.

\section{The advantages and disadvantages of using intermediary services to publish a paper}

Many intermediaries offer to facilitate publications in journals with citation index. The service includes intermediary service (about 1,000 USD), translation (300-500 USD), and journal printing fee (about 500 USD). All these processes take many months. The main disadvantage of using intermediary services is that they will choose journals with a low impact factor due to easy to get papers accepted. Quite often the intermediaries are fraudsters.

\section{An Ethical Issue in Relation to Journals' Policy}

It is known, more than $70-85 \%$ submissions are rejected and not accepted by journals with impact factor. Journals' policy strictly prohibits authors to submit their manuscript to more than one journal concurrently. It is important to avoid paper duplication. At the same time, every author strives hard to be published so as not to lose scientific and practical priority. Therefore the query arises, why authors may not submit own paper(s) to more than one journal at the same time? If author(s) might submit to several journals simultaneously, he/ she/they: (1) Would reduce the time being published; and (2) could choose a better journal with a more high impact factor if several journals accepted their paper. Conventional journal policy seems to be discriminatory to the author(s) to be published first, and the policy further can contribute to loss of copyright [13].

However, if authors submit to only one journal in the same time, they can increase a chance being published in another next journal by improving own paper under comments from previous review(s). For instance, if authors submit own paper in several journals in the same time, then they get similar comments from the journals, and then they can lose more possibilities being successful, because the amount of reliable journals are limited.

\section{Fees Charged for Publication, and Payment}

Once your paper has been accepted for publication, you often need to pay publication fees or article processing charges. Naturally, it depends on the type of journal. There are many high-quality journals where articles are published without paying article-processing charges (diamond open access journal, subscription-based journals, etc.). Nevertheless, most clinical journals request a fee for the publication.

Open-access journals are steadily increasing year by year, for instance, more than $40 \%$ of articles in 2018-2019 were published Open access [14]. Open access is a publishing model for scholarly communication that makes research information immediately and permanently free for everyone to read and download, but usually not for authors to submit. Open-access journals usually charge a fee for processing articles.

There are more than 12,000 journals indexed in Web of Science (Clarivate Analytics), and journals with impact factor $>3$ are $<16 \%$ (www.jcr.incites. thomsonreuters.com). Hence, most medical journals do not charge any publication fees; also most medical clinical journals in Web of Science with impact factor $>3$ require a publication fee of at least 1,000 USD [15]. It is a business also.

\section{Before Paying Article Processing Charges}

The payment method can be a different, and it depends from the country, institutions, journal, authors, etc. This paragraph is devoted to authors who did not receive any funding for their research, and they have to pay publication fees by themselves. Thus, the author(s) can pay by credit card using a secure payment link through an electronic portal provided by the journal, or by bank transfer issuing an invoice number through an account provided by the journal. The second payment method is on 100 160 USD more expensive than the first, because both countries' banks get bank fees.

During bank transfer, you should keep on your credit card sufficient money for the publication payment including bank fee and VAT charges, but 
not exceeding twofold of the publication fee to avoid 2 times remittance due to various computer and bank errors. It is recommended to keep money on credit card in a single currency for coming remittance. Pay note on a specific deadline for payment transaction to avoid admin fee/penalty.

\section{Conclusion}

The advices can help for many researchers to publish their paper in relevant journal with cited indexes, to avoid "predatory" journals and publishers, properly to use intermediary services, to know a journal policy and expectations of good journal editor(s), and avoid many problems within the publication process. The paper can provide a clue how to improve the quality of local journals, make them more attractive for international authors, avoid "predatory" publishing by local authors, and eradicate "predatory" publishing activities in a country. Perhaps research managers may improve the situation by educating their local non-Anglophone authors, reviewers, editors, and publishers to properly write articles in understandable English, search through multidisciplinary and specialist databases, analyze citation and alternative metrics, etc.

\section{Limitations}

Predatory and hijacked journals are becoming more and more inventive. We could not include all the advices for authors in this paper.

\section{Authors' Contributions}

$\mathrm{KO}$ : Design and performance, data collection, carried out the major part of the study and wrote the first draft of the manuscript. GB: execution of parts of the study and compute of data analyses. KM and AT: Data collection and helping in critical revision of the manuscript. All authors read and approved the final manuscript.

\section{Acknowledgments}

The authors thank professor Sandro Vento for tips and researcher Karashash Menlibayeva for technical assistance.

\section{Availability of Data and Materials}

All data generated or analyzed during this study are included in this manuscript.

\section{Consent for Publication}

Our manuscript does not contain any individual person's data in any form. All authors of the manuscript affirm that they had access to the study data and reviewed and approved the final version.

\section{Ethics Approval and Consent to Participate}

The study did not involve any human subjects, human material, human data, or experimental material.

\section{References}

1. Iskander JK, Wolicki SB, Leeb RT, Siegel PZ. Successful scientific writing and publishing: A step-by-step approach. Prev Chronic Dis. 2018;15:E79. https://doi.org/10.5888/ pcd15.180085 PMid:29908052

2. Richtig G, Berger M, Lange-Asschenfeldt B, Aberer W, Richtig E. Problems and challenges of predatory journals. J Eur Acad Dermatol Venereol. 2018;32(9):1441-9. https://doi.org/10.1111/ jdv.15039

PMid:29729106

3. Martins TG, Costa A, Moncada FJ, Martins RV. Hijacked scientific journals: A warning to researchers. Einstein (Sao Paulo). 2016;14(1):113. https://doi.org/10.1590/ s1679-45082016ce3632

PMid:27074242

4. Cortegiani A, Longhini F, Sanfilippo F, Raineri SM, Gregoretti C Giarratano A. Predatory open-access publishing in anesthesiology. Anesth Analg. 2019;128(1):182-7. https://doi. org/10.1213/ane.0000000000003803

PMid:30234529

5. Masten YB, Ashcraft AS. The dark side of dissemination: Traditional and open access versus predatory journals. Nurs Educ Perspect. 2016;37(5):275-7. https://doi.org/10.1097/01. nep.0000000000000064 PMid:27740559

6. Oermann $\mathrm{MH}$, Nicoll LH, Chinn PL, Ashton KS, Conklin JL, Edie $\mathrm{AH}$, et al. Quality of articles published in predatory nursing journals. Nurs Outlook. 2018;66(1):4-10. https://doi. org/10.1016/j.outlook.2017.05.005

PMid:28641868 
7. Beall J. Predatory publishing. Scientist. 2012;26(2):22-3.

8. Hansoti B, Langdorf MI, Murphy LS. Discriminating between legitimate and predatory open access journals: Report from the international federation for emergency medicine research committee. West J Emerg Med. 2016;17(5):497-507. https://doi. org/10.5811/westjem.2016.7.30328

PMid:27625710

9. GasparyanAY, Yessirkepov M, Diyanova SN, Kitas GD. Publishing ethics and predatory practices: A dilemma for all stakeholders of science communication. J Korean Med Sci. 2015;30(8):1010-6. https://doi.org/10.3346/jkms.2015.30.8.1010

\section{PMid:26240476}

10. Brainard J. Articles in "predatory" journals receive few or no citations. Science. 2020;367:129. https://doi.org/10.1126/ science.367.6474.129

11. Memon AR. Hijacked journals: A challenge unaddressed to the developing world. J Pak Med Assoc. 2019;69(10):1413-5.

PMid:31622288
12. Dadkhah M, Maliszewski T, da Silva JA. Hijacked journals, hijacked web-sites, journal phishing, misleading metrics, and predatory publishing: Actual and potential threats to academic integrity and publishing ethics. Forensic Sci Med Pathol. 2016;12(3):353-62. https://doi.org/10.1007/s12024-016-9785-x PMid:27342770

13. Moustafa K. Publishers: Save authors' time. Sci Eng Ethics. 2018;24(2):815-6.

PMid:28155095

14. Olivier P, Erwin ID, Tennant JP, Andrew H, van Hullebusch ED. The growth of open access publishing in geochemistry. Results Geochem. 2020;1:100001. https://doi.org/10.1016/j. ringeo.2020.100001

15. Polat B, Ozmanevra R, Ozmanevra PT, Kazikdas KC. Comparison of the impact factors of subscription access and open access orthopedics and sports medicine journals in the SClmago database. Eklem Hastalik Cerrahisi. 2019;30(2):1637. https://doi.org/10.5606/ehc.2019.64729

PMid:31291866 